\title{
Work Related Conflict Revolved via Mediation
}

\author{
James C. McDermott ${ }^{1}$ \\ ${ }^{1}$ University of Alaska, Fairbanks, USA \\ Correspondence: James C. McDermott, University of Alaska, Fairbanks, Alaska, USA.
}

Received: June 1, 2016

doi:10.5430/ijba.v7n4p55
Accepted: June 29, 2016

Online Published: July 4, 2016

URL: http://dx.doi.org/10.5430/ijba.v7n4p55

\begin{abstract}
The main method of analyzing conflict management focuses heavily on managerial interests of workplace efficiency and productivity. In this paper, the author provides an expertise view point analysis which orients business conflict resolution toward people rather than productivity. The paper provides a practical and meaningful way of dealing with conflict in a manner that acknowledges that specific cases may demand particularized decision-making focusing on individual perspectives. The paper draws on the equity theory to show how employees who perceive a system as fair and just can increase production and thus a positive perception of organizational behavior. Implications for future research could examine the relationship between organizational justice and the more global concepts of rule and level-headedness.
\end{abstract}

Keywords: conflict, mediation, stress, interaction, resolution

\section{Introduction: Work Related Conflicts}

Work related conflict, the study focused on the difference between men and women concerning their communication tactics and their conflict resolution approaches. I found it attention-grabbing to consider article observations like "Boys usually tried to "one up" the other... [While] girls... want to have the same feelings as their friend" (Bailey, 2009, pg. 1). And it struck me how much better a mediator would be prepared in their jobs if they had a sound grasp on gender norms and how gender can impact one's perception. I determined the following comment to be simply illuminating and a must have understanding to be an effective mediator "Men need to remember that women often want to connect with the other person when talking and women need to recognize that men may be more direct." (Bailey, 2009, pg. 2) After reading my comments resulting from a personal interview with Janet McDermott, MSW, LCSW, I believe that you will clearly see how this knowledge concerning gender norms can aid a mediator during the resolving of a conflict process.

Personal interview with Janet McDermott: Janet is a License Clinical Social Worker (LCSW) and for years succeeded as a counselor \& mediator working with our country's warriors both active duty personnel returning from the front line battle lines and with veterans. Janet's expertise was as a counselor working directly with military men and women dealing with Post Traumatic Stress Disorder (PTSD) and this counseling also led to numerous family mediation opportunities over the years. Concentrating on mediation, I asked Janet for an example dealing with a family domestic issue between the military member dealing both with PTSD and with a spouse arguing over an issue at home. Janet told me about her mediation observations concerning one couple and how she employed the five stages of conflict: (Rob 2014) which added valued structure to the mediation process. This personal interview centered on a U.S. soldier and his wonderful wife. Furthermore, I observe that Janet's approach employed the TRIP (Topic, Relationship, Identify, and Process) strategies. (Hocker \& Wilmot, 2014, pg. 291) Additionally, I assured that Janet agreed, as she did, that the mediator "... has no power to render a decision or impose a solution. (Hocker \& Wilmot, 2014, pg. 286)

\section{Latent Stage: Participants Not Yet Aware of Conflict}

"Deployments create a great deal of stress for relationships once the service member returns home." (J. McDermott, personal interview January 19, 2016) Being prior military myself, I asked Janet about the attitudes of her clients who have spent a great deal of time livening 24 hours a day in a hostile environment, where you were constantly on guard to danger and aware that other were plotting to kill you; and then suddenly finding yourself back home her in the United States (U.S.) as mommy or daddy. I would imagine that for many individuals returning from deployments that the transition back to the U.S. that many of these warriors have experienced significant conflict in their close relationships with others. My interview continued, "They may not understand or be aware of the underlying turmoil that is feeding 
the conflict. Due to this discomfort, they begin to avoid stressful situations. The problem with this avoidance then increases the discomfort." (J. McDermott, personal interview January 19, 2016) Topic: a married couple arrived for a mediation session to resolve an issue concerning who would drive pending a vacation where they planned to travel through several states to visit family.

\section{Perceived Stage: Participants Aware a Conflict Exists}

Janet went on to share a mediation situation where the husband suffering with PTSD returning home and dealing with a topic of not being able to allow his wife to drive the family vehicle. Janet explained to me that during the husband's deployment the act of simply driving was a dangerous feat within the battle zone and the fear that developed followed him back to the U.S. "A pre-conflict interview identified that since a recent return from deployment, the husband would not allow his wife to drive, insisting that he only "felt safe" when he was driving. He was "the driver" during his deployment. The wife explained that since his return, when they were out driving to run errands or go shopping, the husband would begin to experience significant distress, become angry, and then demand they return home. The wife would offer to drive, but this was met with a statement "not going to happen". This situation was creating a great deal of conflict in the marriage and concerns for the planned vacation. With the trip scheduled for the near future, and with the amount of driving required for the trip, the couple decided to seek professional help." (J. McDermott, personal interview January 19, 2016)

\section{Felt Stage: Stress and Anxiety}

During the mediation sessions Janet observed that both partners were experiencing high levels of stress and anxiety and of course this ongoing fretfulness might have a negative impact on their marriage. As noted during the interview with Janet it became obvious that it was important during the mediation sessions that the clients needed to understand that avoiding the conflict would most likely lead towards increased angst and anxiety between the couple. So, in summary the felt stage helped the couple to identify a plan to decrease stress and anxiety via decreased avoidance and a stopping of embracement of unsubstantiated fears. They could not ignore the elephant in the room and to the couple's credit they addressed the issue head on. (J. McDermott, personal interview January 19, 2016)

\section{Manifest: Conflict Is Open and Can Be Observed}

Janet asked the couple to identify a recent time and situation where they had experienced stress while driving together. The wife divulged an instance from her recent experience when the couple had driven to a local town to accomplish a little shopping. As they were nearing their destination they came upon an overpass and her husband, just at the site of an overpass, began to express aggravation, to the point where he ended up driving his vehicle clear off the road all in an effort to avoid what he perceived as a dangerous situation and he drove their vehicle onto the side of the road before coming to a stop. After telling her story, the wife stated during the counseling/mediation session that she did not want to live in constant fear of this type of odd behavior response to perceived danger that simply did not exist here in the U.S. Now, during this same session the husband expressed to Janet and his wife that you basically "...never know what might happen when you are driving and you must always be prepared to react to the unexpected." (J. McDermott, personal interview January 19, 2016) but yet his wife insinuated that his new behaviors (since his return from military action overseas) like his reaction to the overpass and forbidding her to drive were completely unacceptable to her. The wife in this case was not prepared to go on a road trip with someone who might head into the ditch without good reason, and she did not like that he forbidden her from driving.

Janet acted like a great coach should by helping the "...parties deal with strong emotions (theirs and others'), and assists the person [s] with a more productive response..." (Hocker \& Wilmot, 2014, pg. 284) Janet went on to state that during this stage of observing the drivers (pun not intended) of conflict that "After much discussion about the situations that created the most discomfort; the couple agreed to try a new response to stress and anxiety triggers. The couple agreed that when they were approaching an over-pass the husband would pull over to the side of the road and allow the wife to drive under the underpass. Once on the other side, when the husband was ready to drive again, the wife would stop and they would again change places." (J. McDermott, personal interview January 19, 2016)

The significances to this mediation strategy for the husband were to acknowledge stressful status and to decide on a new response to his stress. Additionally, it was important for the wife to help him through these stressful moments via incremental steps. In my humble opinion, this stage of formulating a planned response to stress took a mediator with years of training to help provide for win-win negotiations.

\section{Aftermath: Outcome of Conflict, Resolution or Dissolution}

The much happier couple returned to chat with Janet McDermott after they returned from their vacation. According to Janet the couple's entire demeanor had changed and she went on to state "they came into my office hand in hand, with 
big smiles on their faces." They stated they only returned to Janet's office because they needed to thank Janet and let her know the intervention had been successful in resolving the conflict. The wife began by stating it only took four overpasses before her husband was able to begin to develop a new and more rational response to his fear. In the early miles of their trip, she would point out the pending overpass and remind him that he needed to pull over. The wife stated at first he did not want to, but he did because of the mediation agreement. However, after two overpasses and the "fire drill" routine of changing places, the couple began to laugh at themselves and the husband recognize the absurdity effort they were putting into this new behavior [A huge breakthrough]. (J. McDermott, personal interview January 19, 2016)

\section{Summary}

Through the continued mediation process the husband began to communicate openly about his level of discomfort to drive under an overpass and via a supporting spouse and incremental steps he started to drive, plus allow his wife to drive with him in the same vehicle, under overpasses without his over-reacting. With time, he was able to be comfortable allowing his wife to drive again. As Hocker \& Wilmot, 2014, indentified so well “...mediation helps the parties meet their underlying interests rather than fight over positions" (pg. 287). What I saw in this case study was 3 people taking different leadership role to lead to a solution. The mediator led by listening and then pointing the couple towards a negotiated trial with the covert awareness of all that this was chance towards positive change. The husband led by agreeing to try and overcome his PTSD that has clouded his perceptions concerning his wife driving and his driving under overpasses. Plus, the wife who held everything together at home (leadership) while waiting for her husband to come home but discovering war had changed her husband and her willingness to take those baby steps with her husband were congratulatory. As authors Heifetz \& Linsky, 2002, have pointed out concerning leadership and change "...you lead through difficult change, you take them on an emotional roller coaster because you are asking them to relinquish something---a belief, a value, a behavior..." (pg. 116-117)

\section{References}

Bailey, S., J. (2009). Couple relationships: communication and conflict resolution. Retrieved January 21, 2016, from http://store.msuextension.org/Products/Couple-Relationships-Communication-and-Conflict-Resolution_MT20 0917HR.aspx

Heifetz, H., A., \& Linsky, L. (2002). Leadership on the Line. Boston, MA. Harvard Business School Publishing.

Hocker, J. L., \& Wilmot, W. W. (2014). Interpersonal conflict ( $9^{\text {th }}$ ed.). New York, NY. McGraw-Hill Co.

Rob. (2014). 5 stages of conflict and workplace conflict resolution. Retrieved January 19, 2016, from https://blog.udemy.com/stages-of-conflict/ 